\title{
Effect of Ramadan Fasting on Patients With Type Ii Diabetes Mellitus (A Literature Review)
}

\author{
${ }^{1}$ Andriyani Asmuni, ${ }^{2}$ Masyitoh, ${ }^{3}$ Ahmad Khoirul Fajri, ${ }^{4}$ Muhammad Farid Hamzen, ${ }^{5}$ Rohimi \\ Zamzam, ${ }^{6}$ Ernyasih, ${ }^{7}$ Abul A'la Al Maududi, ${ }^{8}$ Dihartawan \\ ${ }^{1-8}$ Faculty of Public Health, Muhammadiyah University of Jakarta \\ K.H. Ahmad Dahlan Street, Cirendeu, Ciputat, South Jakarta, 15419 \\ E-mail: andriyani@umj.ac.id
}

\begin{abstract}
Diabetes Mellitus (DM) or commonly known as diabetes is a disease caused by impaired carbohydrate metabolism due to the pancreas cannot produce insulin or can produce insulin but the body is not able to use insulin effectively and also produces less insulin, so the body is unable to metabolize carbohydrates, fats, and proteins due to insulin deficiency. Insulin is a hormone that regulates the balance of blood glucose in the body. The writing of this article uses a method of literature review or review literature by reviewing several journals and articles about the relationship between fasting and control of diabetes mellitus management. Journals are downloaded or obtained through the journal portal of universities in Indonesia. The process of writing this article is carried out for two weeks. The results showed that Ramadan fasting is related to DM control through DM management. The conclusion is that there is a significant relationship between several journals studied.
\end{abstract}

Keywords: Ramadan Fasting, Type-2 Diabetes Mellitus, Blood Sugar 


\section{INTRODUCTION}

Diabetes Mellitus (DM) or commonly known as diabetes is a disease caused by impaired carbohydrate metabolism due to the pancreas being unable to produce insulin or can produce insulin but the body is unable to use insulin effectively and also produces less insulin, so the body is unable to metabolize carbohydrates, fats, and proteins due to insulin deficiency. Insulin is a hormone that regulates the balance of blood glucose in the body. [1]

According to the International Diabetes Federations (IDF) in 2017 DM is a major problem that continues to grow, the prevalence of people having DM disease globally is $8.8 \%$ in2017 or about 425 million people with a mortality rate of 4 million people worldwide The number of people with diabetes is estimated at the age of 20-79 people.[2]

According to the Ministry of Health of the Republic of Indonesia DM ranks the 6th highest mortality rate in rural areas with a percentage of 5.8\% in 2013. According to Riskesdas in 2013, diabetics accounted for $4.2 \%$ of deaths to urban (15-44 years old) and made the death rate number 2 in the age group (45-54 years) in urban areas with a percentage of $14.7 \%$ in 2007 . Type II DM is the most widely encountered type and the prevalence rate is always increasing in every country. [2]

Diabetes mellitus cannot be cured but can be controlled through the management of diabetes mellitus. Based on the Consensus on the Management and Prevention of type 2 DM in Indonesia in 2011 there are 4 pillars in the management of diabetes mellitus, the 4 pillars include education, physical exercise, pharmacological interventions, and nutritional therapy or meal planning In addition to controlling diet, diabetics can also control their food intake by fasting. [3]

The Prophet (peace be upon him) said, "Fast you, you will be healthy." Bukhari). According to Albiby Fasting can clear toxins and substances that accumulate in digestive tracts, kidneys, and other organs due to preservatives, dyes, artificial sweeteners, cigarette smoke, which accumulate during the years of Ramadan fasting will not be harmful to people with DM but provide many benefits. [3]

Fasting in the sense of language is restraining. In Islam fasting is an activity/activity of worshiping the Creator by refraining from food, drink, lust, and other activities since sunrise or dawn. One of the fasts that must be carried out by Muslims is no exception to the sufferers of DM, namely the fasting of Ramadan as the word of Allah in the Qur'an surah Al-baqarah which means: "O those who believe, it is obligatory upon you to fast as required of those before you so that you fear." [QS. Al-Baqarah (2): 183]. People with DM also must fast for 13 hours in 1 full month to enrich their spiritual life. Fasting during Ramadan is a method of dietary control carried out by people with DM. During fasting, people with DM have a more patterned eating schedule that is two large portions at the time of sahur and breaking the fast. [2] 
Fasting means that a person is not allowed to eat and drink either orally or by injection from sunrise to sunset. Fasting can cause changes in the body's metabolism, caused by changes in the number of carbohydrates or fats consumed. One of the most affected conditions is when a person suffers from type 2 DM. In people with type 2 DM blood, sugar levels can decrease well. But it is also at risk of hypoglycemia. Therefore, in people with type 2 DM who want to fast in Ramadan, it is advisable to counsel about health conditions, nutrition, and physical activity that can be done by people with type 2 DM while fasting Ramadan. [4]

This journal aims to conduct review literature from various sources regarding the relationship between fasting and control of diabetes Mellitus management.

\section{METHODS}

The writing of this article uses the method of a literature review or literature review by reviewing several journals and articles about the relationship between fasting and control of diabetes mellitus management. Jurnal was downloaded or obtained through the journal portal of universities in Indonesia. The process of writing this article is carried out for two weeks from April 20-27, 2020.

\section{RESULTS AND DISCUSSIONS}

According to the results of research conducted by Alfin DKK (2018), it is known that the difference in average blood sugar levels of respondents after fasting Ramadan in the intervention group and control group is $20.22 \mathrm{mg} / \mathrm{dL}$ with a standard error of 9.42. The T-Independent statistical test showed values ( $\mathrm{p}=0.039),(\mathrm{t}=2,147)$, with $\alpha=0.05$.eating $\mathrm{p}<\alpha$ where Ho was rejected, so it can be concluded that there was a meaningful difference in blood sugar levels after Ramadan fasting in the intervention group and control group. [2]

Based on the results of research and discussion on Saputra research (2016) can be concluded several things, namely, there is a significant reduction in blood sugar levels before and after intervention (fasting Monday and Thursday) in the experimental group. There was a significant increase in blood sugar levels before and after the control group. There was a significant influence on blood sugar levels between the experimental group that had been fasting Monday and Thursday and the control group that did not fast Monday and Thursday. [3]

Fasting can lower blood sugar levels, cholesterol, and control blood pressure. That is why, fasting is highly recommended for the treatment of those suffering from diabetes, high cholesterol, obesity, and high blood because fasting can maintain a full stomach due to eating a lot which is one of the main causes of various diseases, especially obesity, hyper cholesterol, diabetes and diseases caused by excess other nutrients (DinKes 2013). Ardi (2014) also supports that fasting helps make glucose levels in the blood more stable due to a more regular diet and relatively similar calorie intake from day today. As well as helping to regulate the increase in glucose and insulin levels in the body. 
Helps glucose levels become lower, lowering blood pressure and triglycerides. Decreased blood sugar levels during fasting are also due to decreased insulin secretion. [1]

According to research conducted by Fatimah (2019), Ramadhan Nutrition Plan (RNP) is an application that can be used by people with diabetes mellitus during Ramadan fasting. In Ramadhan Nutrition Plan (RNP) there is education to increase the knowledge of people with diabetes mellitus as well as the recommended nutritional intake plan during Ramadan. The main purpose of the Ramadhan Nutrition Plan (RNP) application is to ensure that people with diabetes mellitus consume a sufficient number of calories with a balanced proportion of macronutrients at the time allowed to eat while fasting thus reducing the likelihood of hypoglycemia during the fasting period. The next goal is to ensure that patients distribute carbohydrate intake evenly between meals to minimize the occurrence of postprandial hyperglycemia. Furthermore, the purpose of using the Ramadhan Nutrition Plan (RNP) application is to ensure that diabetics and health workers can identify early and lower the chances of developing dyslipidemia and hypertension (International Diabetes Federation and DAR International Alliance, 2016). [4]

In people with type-2 DM who fast Ramadan also obtained varying results, namely a decrease in plasma glucose, a meaningful increase in serum glucose, and an increase in fasting blood glucose that is not meaningful. It is known that glycogen reserves, according to the degree of gluconeogenesis, maintain glucose levels within normal limits at the time of fasting and then followed by breaking the fast. Glycogen reserves in people with type $2 \mathrm{DM}$ with controlled blood glucose are better than in people with type $2 \mathrm{DM}$ with uncontrolled blood glucose. Fasting conditions and most subjects with insulin therapy likely contributed to fasting glucose. In addition, mild changes in blood glucose may also occur in individuals depending on eating habits and energy regulation. [5]

According to Firmansyah (2015), Insulin secretion facilitates the storage of glucose in the liver and muscles as glycogen, stimulated due to eating activities in healthy people. During fasting, plasma glucose levels tend to be low thus lowering insulin secretion. Along with this condition, glucagon and catecholamine levels increase which stimulates the breakdown of glycogen, and at the same time gluconeogenesis increases. During fasting, glycogen stores will be reduced and low plasma insulin levels trigger the release of fatty acids from adipocyte cells. Oxidation of fatty acids produces ketones as a metabolic fuel by skeletal muscle, heart muscle, liver, kidneys, and fat tissue (adipose) This saves the use of glucose which is primarily intended for the brain and erythrocytes. Many studies reveal that generally there are no major problems in diabetic patients, both type 2 and type 1 diabetes, who run fast. Calorie intake is generally reduced although some are unchanged, and gain weight loss during fasting. [6] 


\section{Understanding Shiyam (Fasting)}

a. Shiyam according to language: refrain from something.

b. Shiyam according to the term: refrain from eating, drinking, sexual intercourse of the husband and wife and everything that cancels from dawn to sunset with the intention of therefore Allah.

The basis of the intention of fasting is because of Allah:

1) The Word of Allah SWT:

"But they were not commanded except to purify Allah by purifying the religion of Him in a straight manner." [QS. Al-Bayyinah (98): 5].

2) Hadith of the Prophet Muhammad:

It means: "From Umar r.a. (narrated) that the Prophet (peace be upon him) said: Verily all worship must be with intention, and everyone depends on his intentions..." [Narrated by Al-Bukhari, Kitab al-Iman].

\section{Number of Shiyam Days (Fasting)}

a. Shiyam begins on the 1 st of the month of Ramadan and ends on the last date of Ramadan (29 days or 30 days, depending on the conditions of the month). For this reason, you must know the beginning of Ramadan.

b. Basic must know the beginning of the month of Ramadan:

1) The Word of Allah SWT:

"It is he who makes the sunshine and the moonshine and he sets manila-manila (places) for the journey of the month, that you may know the number of years and the reckoning ( of times)." [QS. Jonah (10): 5]

2) Hadith of the Prophet Muhammad:

"From Abu Hurayrah r.a. (narrated that) he said: The Prophet said: Fast because you see hilal and break the fast because you see it, if you are hindered by your vision by clouds, then perfect the number of Sha'ban thirty days." [Al-Bukhari, and Muslim].

\section{Basic Obligations of Shiyam Ramadan}

1. The word of God;

"O you who believe, it is obligatory for you to fast as is obligated upon those before you that you may fear." [QS. Al-Baqarah (2): 183].

2. Hadith of the Prophet Muhammad:

"From 'Abdullah r.a. (narrated that) he said: The Prophet (peace be upon him) said: Islam is built on five foundations, namely witnessing that there is no god but Allah; praying; paying off zakat; performing Hajj, and fasting in the month of Ramadan." [H.R. al-Bukhari, Muslim, at- Turmudzi, an-Nasa'i, and Ahmad, and this pronunciation is a Muslim pronunciation]. 


\section{The Required and the Not Required to Fast}

1. People who are required to fast, Ramadan, are all Muslims and Muslims who are mukallaf.

2. People who are not obligated to fast Ramadan, and are obliged to change their fast outside of Ramadan are women who experience menstruation and nifas in the month of Ramadan. The scholars have agreed that the law of nifas in terms of fasting is the same as menstruation.

The basis is:

1. Hadith of the Prophet Muhammad:

The Prophet said: "Did not she have menstruating, did not pray and did not fast? They said, "Yes." [HR. Al-Bukhari].

2. "'Aisha r.a. said: We had come to it,' so we were commanded to fast and not be commanded to pray. Muslims].

\section{People Who Are Given Leniency and People Who Can Leave Fasting}

1. A person who is granted dispensation not to fast, and is obliged to change (mengqadla) fasting outside the month of Ramadan:

a. Sick people are common in Ramadan.

b. People who are traveling (travelers).

2. People who can leave fasting and replace it with fidyah 1 mud $(0.5 \mathrm{~kg})$ or more staple food, for each day. a. People who are unable to fast, for example, because of old age and so on.

a. People who are sick.

b. Pregnant women.

c. Women who breastfeed.

\section{Things that Cancel Fasting and Its Sanctions}

1. Eat and drink during the day during Ramadan, fasting is void, and it is mandatory to replace it outside of Ramadan. Allah says: "And eat drink until the light for you is the white thread of the black thread, that is, the dawn..." [QS. Al-Baqarah (2): 187].

2. A husband and wife during the day of Ramadan; His fast is void, and must replace his fast outside the month of Ramadan, and must pay kifarah in the form of freeing a slave; if unable to fast 2 (two) months in a row; If you cannot afford to feed 60 poor people, each person 1 mud staple food.

\section{The Problem of People Who Forget}

The person who eats or drinks forgetting during the day of Ramadan, in a state of fasting, does not break his fast and must continue his fast without any sanction. 


\section{Things to Avoid During Fasting}

1. Saying or doing things that are not following the teachings of Islam, such as anger, lying, slandering, deceiving, saying dirty, berating, making noise, disturbing others, fighting, and all reprehensible deeds according to the teachings of Islam.

2. Gargling or istinsyaq excessively.

3. Kiss your wife during the day, if you can't hold back.

\section{Practices Recommended During Fasting}

1. Doing Qiyamul-Lail on the night of Ramadan (Qiyamu Ramadhan/ Tarawih Prayer).

2. End eating at sahur time.

3. Praying before maghrib (ta'jil) prayer.

4. Pray when breaking the fast, with a prayer that is chanted that shows gratitude to Allah SWT. For example, do'a Dzahabazh zhama'u wabtallatil 'uruqu wa tsabatal ajru Insha Allah.

5. Increase sadaqah and learn/read the Qur'an.

6. Draw closer to Allah using i'tikaf in the mosque, especially on the last ten days of Ramadan.

\section{Implications of Fasting on Health}

Therapy of mental illness with fasting

a. Treating selfishness

b. Treating the nature of anger and restraining emotions

c. Treating the problem of promiscuity for youths (8)

Quoted by [7].

Based on the muhammadiyah tarjih and literature review that the authors studied, the conduct of Ramadan fasting is related to the control of DM through DM management because if the research is held with a time of 30 days or equal to 1 full month of Ramadan can be a significant research result.

\section{CONCLUSIONS AND SUGGESTIONS}

From the results of a review of 5 journals that have been done, it can be concluded that Ramadan fasting is very good for controlling DM through DM management. There are significant results of the relationship between people with type $2 \mathrm{DM}$ and fasting in Ramadan so that if Ramadan fasting is carried out 30 days or equal to 1 month with routine can make glucose in people with DM become more regular, reduce dependence on drugs, improve the health of organs and improve discipline. But for people with DM who fast must manage their condition when fasting so as not to aggravate their condition that causes other problems.

People with Diabetes Mellitus (DM) should better regulate diet when sahur and iftar and diligently exercise physically but choose light to moderate exercise, avoid excessive exercise when fasting. 


\section{REFERENCES}

[1] F. Fatmaningrum, E. Suprayitno, and Widaryati, "THE EFFECT OF THURSDAY'S SUNNAH FASTING ON BLOOD GLUCOSE LEVELS IN TYPE 2 DIABETES MELLITUS PATIENTS AT PUSKESMAS BERBAH, SLEMAN, YOGYAKARTA," published by the publication, 2017.

[2] R. Alfin, Busjra, and R. Azzam, "THE EFFECT OF RAMADAN FASTING ON BLOOD SUGAR LEVELS IN PATIENTS WITH TYPE II DIABETES MELLITUS IN PURWAKARTA CITY HEALTH CENTER IN WEST JAVA IN 2018," Journal of Telenursing (JOTING) 1 (1) 191-204, 2018.

[3] A.B. W. SAPUTRA, "THE EFFECT OF FASTING MONDAY AND THURSDAY ON BLOOD SUGAR LEVELS WHEN IN PEOPLE WITH TYPE 2 DIABETES MELLITUS IN DUKUH KASIHAN, BANTUL, YOGYAKARTA," published by THE PUBLICATION, 2016.

[4] A. D. Fatimah, "LITERATURE REVIEW OF RAMADAN FASTING MANAGEMENT FOR PEOPLE WITH TYPE 2 DIABETES MELLITUS," JUMANTIK Journal Vol. 4 No.2, vol. 4.

[5] Khomimah, S. waspadji, and M. Abdullah, "changes in glycemic control and plasminogen activator inhibitor 1 in people with type 2 diabetes mellitus who fast Ramadan RSUPN Cipto Mangunkusumo," Indonesian disease journal vol 1 no. 1, 2014.

[6] M. A. Firmansyah, "The Effect of Ramadan Fasting on Several Health Conditions," CDK-230/ vol. 42 no. 7, th. 2015, 2015.

[7] The Assembly of Tarjih and Tajdid. Head of Muhammadiyah Center, "Guidance of Worship in Ramadan," 2011. 